\title{
DETERMINANTS OF TECHNICAL EFFICIENCY AMONG LOWLAND RICE FARMERS IN ENUGU STATE, NIGERIA: A STOCHASTIC FRONTIER PRODUCTION FUNCTION APPROACH
}

\author{
OKOH, T. C ${ }^{* 1}$; OPATA, P.I ${ }^{1}$; IBE, J .C ${ }^{1}$; ONYENEKWE, S. C ${ }^{1}$; IKUBAIYEJE, K. P $^{2}$; ETTUM, P.O ${ }^{1}$ \\ Department of Agricultural Economics, University of Nigeria, Nsukka ${ }^{l}$ \\ Department of Agricultural Extension and Management Kabba College of Agriculture \\ $D A C / A B U$ Zaria $^{2}$ \\ Corresponding Author: timothynonsookoh@gmail.com
}

\begin{abstract}
The study examined the determinants of technical efficiency among lowland rice farmers in Enugu State, Nigeria. Primary data were sourced from rice producers through the use of welldesigned questionnaires. The study was conducted in four agricultural zones of Enugu State, during the 2017/2018 cropping season. Multistage and simple random sampling technique was employed to select 300 sampled rice farmers for the study. Cobb-Douglas stochastic production frontier function was used for the analysis. The result revealed that (98\%) of random variation in the output of farmers was because of their inefficiency in their use of productive inputs in the study area. .Apart from farm size with estimated coefficient of (0.0531), fertilizer (0.0329), seed (0.2319), labour (0.0804) and agro-chemical (0.1711) were underutilized by the rice farmers. The average technical efficiency for the farmers was 0.71 implying that, on the average, the respondents are able to obtain $71 \%$ of potential output from a given mixture of production inputs. Thus, in a short run, there is a minimal scope (29\%) of increasing the efficiency, by adopting the technology and techniques used by the most technically efficient farmer. High cost of inputs $(M S=3.69)$, bad roads $(M S=3.67)$, poor credit accessibility $(M S=3.40)$ and inadequate storage facilities $(M S=2.90)$ were found to be the major constraints of the rice farmers. The study recommends that in order to improve efficiency of resource use by the farmers in the study area, more of labour, seed, fertilizer and agro-chemicals should be utilized.
\end{abstract}

Keywords: Rice paddy, yield, rain fed, mean, agro-ecological zones.

https://dx.doi.org/10.4314/jafs.v19i2.7

\section{INTRODUCTION}

Rice (Oryza sativa), a grain of the cereal family is the most commonly consumed staple food world over (Ndubueze-Ogaraku \& Ogbonna, 2016). It is to a great extent a staple food consumed in Nigeria and remains a staple food for greater number of the world's population. Nigeria ranks tops in rice production in West African sub-region (Ndubueze-Ogaraku \& Ogbanna, 2016). In 2019, Nigerian paddy rice production was estimated at 8,435,000 tonnes, this consisting $66 \%$ of the total output in Sub-Saharan Africa (United States Department of Food and Agriculture, USDA, 2019). This figure represents an increase on the nation's rice output which stood at 7,564,050 tonnes in 2016. The rise in rice output over time was as a result of increase in the number of hectares cultivated (Binuyo et al; 2016). In recent time, government of Nigeria has embarked on a concerted effort to make the country self-

Journal of the Faculty of Agriculture and Veterinary Medicine, Imo State University Owerri website: www ajol.info 
reliant in rice production by the year 2020 under its current Central Bank of Nigeria $(\mathrm{CBN})$ anchor borrowers program (USDA, 2018). This initiative is an answer to the perceived threat of continuous importation of rice into the country since 1990's, which has the capacity to replace local production if not curbed. According to (Ajoma et al, 2016; Opata et al 2018) domestic production is not at par with local demand preceding food insufficiency problems thus requiring the importation of rice. Amechina \& Eboh (2017) opined that Nigeria is the highest importer of rice in the West African Sub-region. According (FAO, 2012) estimates, Nigeria rice import between 2003 and 2013 stood at 17, 206, 077 metric tons with an average import of 1, 564,188 metric tons annually. However, in recent time the federal government of Nigeria has put measures in place to put to a stop the spate of rice importation into the country. These measures include outright ban of rice importation, boarder closure, and non-issuance of foreign exchange to rice importers by $\mathrm{CBN}$ amongst others. According to USDA index, Nigeria was the second largest importer of rice in 2016 at $2 \mathrm{mmt}$ only behind china at $5 \mathrm{mmt}$ prior to the boarder closure in 2019 (premium times, 2021) as of June 2020, the ranking shows that Nigeria is the fourth largest importer of rice in the world. Despite the little successes recorded in curbing the spate of rice importation into Nigeria and the improvement in local production, its consumption rate has increased astronomically. This increase in consumption rate can be attributed to population growth, increase in per capita income and change in consumption pattern of people (Amechina \& Eoh, 2017). In 2018 alone, the consumption rate has risen to 7 million metric tons with only 2.7 million metric tons produced by the local farmers (FMARD, 2018). Nigeria spent about US $\$ 39,787$ thousand in importation of rice in the year 2016. The continuous dependency on rice import to make-up for the shortages in local production tends to constitute a serious danger to the nation's meager foreign currency reserves that could be used in the importation of capital goods like machineries. This trend of rice importation if not abated, could place Nigeria in a position of constantly grappling with the fluctuations of rice price internationally with its attendance unreliability of supply (Binuyo et al., 2016).

Production of rice in Nigeria can be practiced in the following ecological systems namely: rain fed upland, rain fed lowland, irrigated lowland and mangrove rice (Amechina \& Eboh, 2017). In 2017, rice paddy yield in Nigeria was about 7,826,120 metric tons. A greater percentage $(97 \%)$ of these was cultivated in lowland rainfed, and irrigated lowland system. The other 3\% comes from upland ecologies (FAO, 2017). Lowland rainfed rice is the major production systems in Enugu State (Ajoma et al, 2016, Opata et al, 2018). Lowland rice however, is the cultivation of rice on plain flooded or irrigated land and is referred to as swamp rice, wet rice or flooded rice cultivation. Lowland rice production is of two types namely; rain fed lowland rice farming and irrigated lowland rice farming. Rain fed lowland rice is the most important system. It dominates over half of total area under rice cultivation in Nigeria (FAO, 2017). Lowland rice farming is commonly found in areas around the wetlands of River Niger, River Benue and Kaduna River in the north; similarly, lowland rice farming is also practiced in some states in the South like Ebonyi, Enugu and Cross-River (Kamai et al., 2020).

Ndubueze-Ogaraku \& Ogbonna (2016), defined efficiency as the extent to which productive resources such as land, seed, labour, agrochemicals and so on are used to generate output without wastages. Efficiency is an integral aspect of increasing production particularly in a country where resources are 
inadequate and tendencies of developing new technologies are not forthcoming (NdubuezeOgaraku \& Ogbonna, 2016). Ineffectiveness of farmers in using of productive inputs and low acreage under cultivation has been attributed to as the major causes of low productivity of Nigerian rice sector (Binuyo et al, 2016). Furthermore, past studies reveals that it is possible to raise output by decreasing inefficiency without putting more resources into use or developing new technology (Okello et al., 2019). Technical efficiency therefore, is the relative easiness to generate highest output from a given input bundle, considering the readily obtainable technology. Thus, the determination of efficiency levels of lowland rice farmers in Enugu State is the major concern of this study. As a result, the differentials in efficiencies among farms are explained. This could be a major policy instrument and could also help framers to establish new ways of improving efficiencies. Although past studies abound which tends to measure efficiency differentials across farms with simple tools and measures such as ordinary least square (OLS) and yield per hectare which are easy to apply, but hardly indicates the cause of any observed differences among farms. Yield per hectare figure are of little use when the amount of non-land input use such as labour and fertilizer vary across farms. Thus, at the moment there is no complete and current information in respect to technical efficiency of lowland rice farmers in Enugu State.

\section{MATERIALS AND METHODS}

\section{The Study Area}

The study was carried out in Enugu State, Nigeria. Enugu is a State in Southern Nigeria. The State is positioned at latitude $5^{0} 56^{1} \mathrm{~N}$ and $7^{0} 5^{1} \mathrm{~N}$ of the equator and longitude $6^{0} 53^{1} \mathrm{E}$ and $7^{0} 55^{1} \mathrm{E}$ of the Greenwich meridian (Anyadike, 2002). The State has land mass of about $8,022.95 \mathrm{~km}^{2}$ with 17 Local Council Areas (Enugu State Agricultural Development
Program) (ENADEP, 2008). Demographically, the state has about 3,257,298 persons (NPC, 2006). The State is bounded with Anambra State to the west, Kogi State to the northwest, Benue State to the northeast, Ebonyi State to the east, Abia State and Imo State to the South, (Enugu State Official Gazzete, 2017).

The climate of the state is equatorial in nature with dry and rainy periods. The rainy period starts in April and ends in October while the dry period occurs from November to April. The wettest months are between July and September. The average annual precipitation ranges from $1500 \mathrm{~mm}$ northwardly to more than $2000 \mathrm{~mm}$ southwardly (Ukwu et al; 1998). The average temperature ranges from $15.6^{\circ} \mathrm{C}$ in its coolest months to $26.7^{\circ} \mathrm{C}$ in hottest months. The State is commonly rural and agrarian, with about $68 \%$ of her working population engaged in farming. Crop farming is the predominant agricultural practice in the State. Edible crops cultivated in the State include maize, rice, vegetables, yam, among others. Tree crops grown are cashew, mango, orange oil palm and so on (National Agricultural Extension and Research Liaison Services and Project Coordinating Unit NAERLS and PCU, 2006). However, farm animals like sheep, goat, fowls and cattle are raised in most parts of the state though in small quantities.

Enugu State is divided into six (6) agroecological zones (ENADEP, 2012). The agroecological zones and the respective Local Government Areas are as follows:

Nsukka Zone: Igbo-Etiti, Nsukka and Uzouwani LGA's; Enugu-Ezike Zone: Igbo-Eze North, Udenu and Igbo-Eze South LGAs; Enugu Zone: Enugu North, Enugu East and Isi-uzo LGAs; Agbani Zone: Nkanu East, Enugu South and Nkanu West LGAs; Agwu zone: Agwu, Oji-river and Aninri LGAs; and Udi Zone: Udi and Ezeagu LGAs.

Journal of the Faculty of Agriculture and Veterinary Medicine, Imo State University Owerri website: www ajol.info 


\subsection{Sampling Procedure}

Multi-level random sampling technique was used to select respondents from the list of rice farmers obtained from ENADEP. The rice farmers on this list comprised the sample frame for the research. In the first stage, four agro-ecological zones namely; Agwu zone, Nsukka zone, Agbani zone and Enugu zone were purposively selected for their prominence in rice farming in the State. The second stage involve a deliberate selection of four Local Council Areas; Aninri in Agwu zone, Uzo-uwani in Nsukka zone, Nkanu East in Agbani zone and Isi-uzo in Enugu zone, as well owing to predominance of rice farming in these areasagro-ecological zones and the respective LGA's are as follows:

- Nsukka Zone: Igbo-Etiti, Nsukka and Uzo-uwani LGA's

- Enugu-Ezike Zone: Igbo-Eze North, Udenu and Igbo-Eze South LGAs;

- Enugu East Zone: Enugu North, Enugu East and Isi-uzo LGAs;

- Agbani Zone: Nkanu East, Enugu South and Nkanu West

- Agwu zone: Agwu, Oji-ver and Aninri LGAs; and

- Udi Zone: Udi and Ezeagu LGAs.

\subsection{Sampling Procedure}

Multi-level random sampling technique were used to select respondents from the list of rice farmers obtained from ENADEP.The rice farmers on this list comprised the sample frame for the research. In the first stage, four agro-ecological zones namely; Agwu zone, Nsukka zone, Agbani zone and Enugu East zone were purposively selected for their prominence in rice farming in the State. The second stage involve a deliberate selection of four local council areas Aninri in Agwu zone; Uzo-uwani in Nsukka zone, Nkanu East in Agbani zone and Isi-uzo in Enugu East zone, as well owing to predominance of rice farming in these areas. In the third stage, three (3) communities (Oduma, Okpanku and
Nenwe) from Aninri LGA and two (2) communities each (Adani and Asaba) from Uzouwani LGA, (Ugbawka and Amagunze) in Nkanu East LGA, and (Eha-Amufu and Neke) in Isi-Uzo LGA were deliberately chosen because of their dominance in lowland rice farming in the areas, giving a total of nine (9) communities selected. The last stage involved a probable selection of farmers from the list compiled by trained enumerators in each of the communities at a constant rate. Thus, the sum of 300 respondents was sampled for the research. Detailed list of the selection is given in Table 1 below.

\subsection{Data Collection and Analysis}

Primary data were gathered by the use of both well-designed questionnaire and interview scheduled. Descriptive and numerical information on important variables such as (a) the socio-economic characteristics of the rice farmers such as age, household size, educational level, farming experience, cooperative membership, extension contact, farmsize and amount of credit received; data on production factors such as fertilizer $(\mathrm{kg})$, seed $(\mathrm{kg})$, agrochemical (litres), labour (mandays) and output (rice $(\mathrm{kg} / \mathrm{ha})$ ) data. The information that was collected is from the 2017 cropping season.

\section{Data Analysis}

The data obtained were examined using both inferential and attributive statistics. Frequencies, averages and percentages were used in analyzing the socio-economic attributes of the respondents, output and input variables and the spread of efficiency levels.

A common probability test ratio was performed to establish whether the rice farmers were entirely technically efficient.

A Cobb-Douglas random production function frontier that included inefficiency variables were roughly calculated using Maximum Likelihood Estimation (MLE) method to obtain the determinants of technical efficiencies of various farms.

Journal of the Faculty of Agriculture and Veterinary Medicine, Imo State University Owerri website: www ajol.info 


\section{Model specification}

The stochastic production function frontier was used to estimate the technical efficiency of the lowland rice farmers. The implicit form of the model was specified as below:

$\mathrm{Y}=\mathrm{f}\left(\mathrm{X}_{\mathrm{i}}, \beta\right)+\mathrm{e}_{\mathrm{i}} \ldots \ldots \ldots \ldots \ldots \ldots \ldots \ldots \ldots \ldots \ldots \ldots \ldots$

$\mathrm{e}_{\mathrm{i}}=\mathrm{V}_{\mathrm{i}}-\mathrm{U}_{\mathrm{i}}$

Where,

$\begin{array}{lll}\mathrm{Y} & = & \text { Output of rice }(\mathrm{kg}) \\ \mathrm{X}_{\mathrm{i}}= & \text { Vector inputs used by the ith } \\ \text { farm } & \\ \beta \quad= & \text { a vector of the parameter to be } \\ \text { estimated } & \\ \mathrm{e}_{\mathrm{i}}= & \text { Composite error term } \\ \mathrm{V}_{\mathrm{i}}= & \text { random error beyond the }\end{array}$

control of lowland rice farmers

$\mathrm{U}_{\mathrm{i}}=$ technical inefficiency effects

$f\left(X_{j}, \beta\right)=\quad$ appropriate functional form of the vector

A general stochastic frontier production model as expounded by Aigner, Lovell and Scmidt (1997) is expressed implicitly as:

$1_{n} Y_{n}=\beta_{n}+\sum \beta_{j} 1_{n} X_{i j}+V_{i}-U_{i}---------------3$

The randomly determined frontier function for estimating the input and output relationship of lowland rice farming and technical efficiency of lowland rice farmers is specified by the Cobb-Douglas frontier production function, which is expressed explicitly as follows:

$\mathrm{I}_{\mathrm{n}} \mathrm{Y}_{\mathrm{i}}=\beta_{0}+\beta_{1} \mathrm{I}_{\mathrm{n}} \mathrm{X}_{1}+\beta_{2} \mathrm{I}_{\mathrm{n}} \mathrm{X}_{2}+\beta_{3} 1_{\mathrm{n}} \mathrm{X}_{3}+\beta_{4} 1_{\mathrm{n}} \mathrm{X}_{4}$ $+\beta_{4} 1_{n} X_{4}+\beta_{5} I_{n} X_{5}+\left(V_{i}-U_{i}\right) \ldots 4$

Where,

$\mathrm{I}_{\mathrm{n}} \quad=\quad$ natural logarithm to base e

$\mathrm{Y}_{\mathrm{i}} \quad=\quad$ output of rice in $\mathrm{kg}$

$\mathrm{B}_{0}=$ constant or intercept

$\mathrm{X}_{\mathrm{I}}=$ farm size (ha)

$\mathrm{X}_{2}=$ total labour use (man-hours) per ha

$\mathrm{X}_{3}=$ seed quantity $(\mathrm{kg})$

$\mathrm{X}_{4}=$ fertilizer quantity $(\mathrm{kg})$

$\mathrm{X}_{5}=$ agrochemical quantity (litres) $\beta_{1}-\beta_{5}=$ unknown variables to be calculated

$\mathrm{V}_{\mathrm{i}}=$ statistical error and the other events greater than the farmers' control such as topography weather, and other factors not specified and can either be zero (0), positive or negative.

$\mathrm{U}_{\mathrm{i}}=$ non-negative random variable associated with the farmers' technical inefficiency in production and assumed to be independently distributed.

The technical inefficiency effects $U_{i}$, is affected by the farmers' socio-economic characteristics and is defined by:

$\mathrm{U}_{\mathrm{i}}+\alpha_{0}+\alpha_{1} 1_{\mathrm{n}} \mathrm{Z}_{1}+\alpha_{2} 1_{\mathrm{n}} \mathrm{Z}_{2}+\alpha_{3} 1_{\mathrm{n}} \mathrm{Z}_{3}+\alpha_{4} 1_{\mathrm{n}} \mathrm{Z}_{4}+$ $\alpha_{5} 1_{\mathrm{n}} Z_{5}+\alpha_{6} 1_{\mathrm{n}} Z_{6}+\alpha_{7} 1_{\mathrm{n}} Z_{7} \ldots \ldots \ldots \ldots . .5$

Where,

$\mathrm{U}_{\mathrm{i}} \quad=$ technical inefficiency effect of the ith farmer

$\alpha_{0}=$ constant

$\alpha_{1}-\alpha_{7}=\quad$ parameters to be estimated

$\mathrm{Z}_{1}=$ Age of the farmers (years)

$\mathrm{Z}_{2}=$ Lowland rice farming experience (years)

$\mathrm{Z}_{3}=$ Household size (number of persons)

$\mathrm{Z}_{4}=$ Education in years

$\mathrm{Z}_{5}=$ Extension contact (dummy: 1 contacted, 0 otherwise)

$\mathrm{Z}_{6}=$ Access to credit (dummy: 1 accessed, 0 otherwise)

$\mathrm{Z}_{7}=$ Membership of farmers' group/association (dummy: 1 member, 0 otherwise)

\section{RESULTS AND DISCUSSION}

The outcome of the determinants of technical efficiency of rice producers in the research area were shown in Table 2. The study showed that the common log probability function was -169.5252 . The $\log$ probability ratio score shows the score that makes as large as possible the combined densities in the estimated model. Therefore, the functional form Cobb- Douglas employed in this

Journal of the Faculty of Agriculture and Veterinary Medicine, Imo State University Owerri website: www ajol.info 
Volume 19, Number 2, October 2021, pp $63-74$

estimation is a sufficient substitution of $t$ he data set. Sigma-squared $\left(\delta^{2}\right)$ has the value of 0.3209 , signifying that the differences in the technical efficiency of the various farms are caused by $32.09 \%$ of the error term. The variance ratio or gamma $(\gamma)$ value was estimated at 0.9805 or $98 \%$. It implies that about $98 \%$ of the variation between frontier output and observed output were because of technical inefficiency effect (UI). This statistics gamma, was highly significant at $(\mathrm{P}<0.01)$ likelihood level. This justifies the option of the inefficiency variables that have been chosen for this model. This is in tandem with the concept that true $\gamma$-value should be more than zero. This suggests that $98 \%$ of stochastic difference in the yield of rice farms was because of the farmers' inefficiency in their various farms and not because of stochastic variability. Reducing the influence of the effect of gamma $(\gamma)$ will highly improve technical efficiency of the farmers and thus, raise yield since factors are under the control of the farmer.

The results on the determinants of technical efficiency of rice farmers in the study area revealed that fertilizer, seed, labour and agrochemical notably affected technical efficiency of the rice farmers at $1 \%$ and $5 \%$ respectively while the estimated coefficient of farm size was insignificant statistically. The mean technical efficiency for the respondents was 0.71 suggesting that, on the average, the farmers are capable of obtaining $71 \%$ of possible yield from a given set of production factors. Hence, in the interim, there is a smallest possible amount (29\%) of raising the efficiency, by selecting the methods and techniques employed by the most technically efficient farmer. The coefficient of farm size as estimated was 0.0531 which was positive but statistically insignificantly different from zero.

The labour coefficient was 0.0804 which is positive and statistically significant at 5\% level. This implies that labour is a key efficiency factor in rice farming in the area under study. The findings is in conformity with the findings of Umoh (2016) and Opata et al., (2018) which indicated the relevance of labour in agricultural productivity and efficiency specifically in Sub-Saharan African countries where mechanization is inadequate on fragmented farms.

The coefficient of seed estimated to be 0.2319 was positively significant at $1 \%$ level of probability. This signifies that if the amount of seed is increased by $1 \%$, output level would increase by a margin of $23.19 \%$ keeping all other inputs constant. This is in agreement with the findings of Shehu, et al. (2010) who noted that estimated coefficient of labour and seed inputs where positive as anticipated and significant at $1 \%$ level of probability which suggests that increase in rice output can be achieved through seed intensification and engagement of more labour.

The coefficient of fertilizer was 0.0329 which is positive and statistically significant at $1 \%$ level of probability. This suggests that $1 \%$ increase in fertilizer will raise output of rice by $3.29 \%$ in a ceteris paribus case. This investigation agrees with the work of (Opata et al., 2018; and Osanyinlusi \& Adenegan, 2016) who stated that fertilizer is a vital land supplement because it improves land fertility by increasing per hectare yield of rice.

The estimated coefficient of agro-chemical quantity was 0.1711 which is expectedly positive and significant statistically at $5 \%$ alpha level. This indicates that a unit rise in the quantity of agro-chemical will increase output by a margin of $17.11 \%$ all things being equal. This research agrees with the observations of Opata et al., (2018) which observed a positive and significant relationship between quantity of agrochemical and rice output.

\section{Journal of the Faculty of Agriculture and Veterinary Medicine, Imo State University Owerri} website: www ajol.info 
Volume 19, Number 2, October 2021,pp $63-74$

The estimated outcome of the ineffici ency model is presented in the lower part of Table 2. Generally a negative sign of the variables in the inefficiency model indicates that concomitant variables decreases technical inefficiency, while a positive sign raises technical inefficiency. From the results, it can be discovered that all variables in the inefficiency model have negative coefficients except for age and credit access which was positive. This implies that experience in farming, educational level, extension contact, cooperative membership and household size decrease with increase inefficiency. Put in another way, increase in these variables except for age and access to credit increases the efficiency of the farmers in the study area. For age, inefficiency increases with aging. This result is expected due to degenerating effect of age. The positive effect of age is in line with the work of Binuyo et al, (2016) and Okorie (2012) while the negative coefficients of farming experience, household size, educational level, extension contact and cooperative membership agree with the work of Ogundari \& Ojo (2006) and Binuyo et al, (2016). The coefficient of access to credit is positive and statistically not significant. This implies that credit access does not lead to increase in technical efficiency of the respondents.

The frequency distribution of the technical efficiency estimates for rice farmers in the area as obtained from the random frontier model is shown in Table 3. It revealed that $79 \%$ of the respondents had technical efficiency (TE) of 0.61 and more whereas $21 \%$ of the respondents produced at less than 0.60 levels of technical efficiency. The farmer with the most excellent and worst practice had technical efficiencies of 0.94 and 0.11 respectively with mean (TE) of 0.71 . This suggests that output fell by $29 \%$ on the average from the highest possible level that could be achieved due to inefficiency. The huge difference indicates possibility for adjustment by some farmers. The mean technical efficiency in this study is above that of Ajibefun (2002) and Binuyo et al, (2016) which was 0.63 for small scale rain fed lowland rice farmers in Ogun State, Nigeria. Ndubueze-Ogaraku \& Ogbonna (2016) reported a mean (TE) of $83 \%$ among small scale $(<3$ hectares) rice farmers in Abia state, Nigeria.

The findings from this study signifies that if the average farmer in the sample was to achieve technical efficiency of his most efficient counterpart, then the average farmer could obtain a $24 \%$ cost saving [that is, 1 $(0.71 / 0.940]$ or rise in output. Similarly, the most technical inefficient farmer in the area could raise output by $89 \%$ [that is, $1-(0.1$ 1/0.94)]. This finding is in line with (Binuyo et al., 2016) who noted that mean farmer in Niger State could benefit cost reduction of about $48 \%$ if he accomplishes the level of the most efficient farmer amongst the respondents in the study area.

\section{CONCLUSION}

From the results of this investigation, the mean technical efficiency as estimated was 0.71 and it is obvious here that lowland rice farming in the study area did not reach the frontier of production. Similarly, from the findings, $79 \%$ of the farmers have an efficiency level above 0.60 . This implies that about three-quarter of the sampled rice farmers had technical efficiency above 0.60. Farm specific factors which significantly and positively influence technical efficiency are labour, seed, fertilizer and agrochemical while farming experience, educational level, extension contact; household size and cooperative membership are major socioinstitutional determinants of technical efficiency in lowland rice farming. There is need to intensify the frequency of contacts between extension agents and farmers as this will lead to increase in technical efficiency. This would only happen when extension agents disseminate appropriate technologies to farmers Journal of the Faculty of Agriculture and Veterinary Medicine, Imo State University Owerri website: www ajol.info 
and follow-up such technologies through $\mathrm{p}$ roper monitoring of farmers 'activities to achieve desired result. Therefore there is considerable scope for increase in rice output through improvement in technical efficiency of the rice farms.

\section{RECOMMENDATIONS}

It was noticed from the findings that none of the rice farms is able to reach the rice production frontier; therefore, the rice farmers are inefficient. Government and private organizations should show commitment in the supply of inputs such as fertilizer, agrochemicals and farm machineries at subsidized rate in order to raise the efficiency level of farmers. Seed is one the production resources that significantly and positively affects rice production in the study area. Hence, timely and adequate provision of seeds to the farmers should be facilitated by the government. Farmers should be encouraged to plant certified seeds obtained from seed companies or dealers instead of planting grains as majority of them currently does to increase the yield of the crop.

Youths should be encouraged to venture into rice production in the area as younger farmers is likely to be more efficient in combining scarce resources for increased productivity than older farmers.

Extension services should be intensified to teach and motivate farmers to embrace improved farming practices for efficient utilization of inputs and hence increase the yield of rice crop.

\section{COMPETING INTERESTS}

Authors have declared that no competing interests exist. 


\section{REFERENCES}

Aigner, D. J., Loveli, C. A. K., \& Schmidt, P.P (1997). Formulation and estimation of stochastic production function model. Journal of Economics, 6(1), 22 1-237.

Ajibefun, I. A. (2002). Analysis of policy issues in technical efficiency of small scale farming using the stochastic frontier production function; with application to Nigerian farmers. Paper presented at the International Farm Management Association Congress, Wagningen, Netherland, July 2002.

Ajoma, C., Ezihe, J. A. C., \& Odoemenem, I. U. (2016). Allocative Efficiency of rice production in Cross River State, Nigeria: A Production Function Approach. IOSR Journal of Agriculture and Veterinary Science 09(08):32-38.

Amechina, E. C., \& Eboh, E. C. (2017). Resource use efficiency in rice production in the lower Anambra irrigation project, Nigeria. Journal of Development aand Agricultural Economics, 9(8), 234-242.

Anyadike, R. N. (2002). Climate and vegetation. In G. E. K. Offormata (Eds.), A survey of the Igbo nation, Onitsha; African First Publishers Limited.

Binuyo, G., Abdulraham, S., Yusuf O., \& Timothy A. J. (2016). Technical efficiency of rainfed-lowland rice production in Niger State, Nigeria. Asian Journal of Agricultural Extension, Economics \& Sociology, 9(4);1-12.

Central Bank of Nigeria, CBN (2004). Annual Report and statement of Accounts, CBN Publication.

Central Bank of Nigeria, CBN (2006). CBN Statistical Bulletin (2006).

Coelli, T .J. (1995). Recent developments in frontier modelling and efficiency measurement. Australian Journal of Agricultural Economics 39 (3).
Enugu State Agricultural Development Programme, ENADEP (2008). A publication of Enugu State Government of Nigeria.

Enugu State Government Official Gazzete (2017). An official gazzete published on the web by the Enugu State government. No 76 .

Federal Ministry of Agriculture and Rural Development, FMARD (2018). Ministerial press briefing by Minister of Agriculture and Rural Development on the State of Nigerian Agriculture

Food and Agricultural Organization, FAO (2012). Rice Information: FAO Statistics Division. Accessed on May 15, 2021, from the website http://beta.irn.org.

Food and Agricultural Organization FAO (2017). Rice Statistics. Accessed on July 1, 2021, from the website htt://www.riceweb.org.

Kamai, N., Omoigui, L. O., Kamara, A. Y., \& Ekeleme, F. (2020). Guide to rice production in Nothern Nigeria. Revised edition 2020 .

National Agricultural Extension and Research Liason Services (NAERLS) and Project Cordinating unit (PCU), (2006). Field situation assessment of 2006 wet season agricultural production in Nigeria. Report of a study conducted by NAERLS and PCU.

National Population Commission (NPC) (2006). Census report. Abuja FCT.

Ndubueze-Ogaraku, M. E., \& Ogbonna, M. C. (2016). Analysis of Technical Efficiency ands its determinants in rice production: Evidence from Abia State, Nigeria. Nigerian Agricultural policy Research Journal 1(1): 38-49.

Ogundari, K., \& Ojo, S. O. (2006). An examination of technical, economic and

Journal of the Faculty of Agriculture and Veterinary Medicine, Imo State University Owerri website: www ajol.info 
allocative efficiency of small farms: the case study of cassava farmers in Osun State of Nigeria. Journal of Central European Agriculture, 7(3), 423-432.

Okello, D. M., Wabbi, J. B., \& Mugonala, B. (2019). Farm level allaocative efficiency of rice production in Gulu and Amulu districts, Northern Uganda. Journal of Agriculture and Food Economics 7(9). https://doi.org/10.1186/s40100-019-0140$\mathrm{x}$

Okorie, O. J. (2012). Level of adoption of improved cassava varieties and the profitability of cassava production in Enugu State, Nigeria. Unpublished M.Sc thesis presented to the Department of Agricultural economics, Faculty of Agriculture, University of Nigeria, Nsukka.

Opata, P. I., Nweze, N. J., Ezeibe, A. B., \& Mallam, M. (2018). Efficiency of irrigated and rain-fed (oryza sativa) rice producers in Fadama Agriculture, Nigeria. Expl agric.: page 1 of $13 \mathrm{C}$-Cambridge University Press 2018 doi:10.1017/S0014479718000212

Osanyinlusi, O. I., \& Adenegan, K. O. (2016). The determinants of rice farmers' productivity in

Ekiti State, Nigeria. Greener journal of Agricultural sciences (ISSN: 2276.7770). (2): 049-058. Doi:10.15580/GJAS.2016.2.122615174
Premium Times (2021). How Nigeria has fared in rice production since 1999. Premium times banking magazine: Accessed on $8^{\text {th }}$ October, 2021, from the website

http://www.premiumtimesng.com/agricult ure/agric-news/402767.

Shehu, J. F., Iyortyer, J. I., Mshelia, S. I., \& Jongur, A. A. U. (2010). Determinants of yam production and technical efficiency among yam farmers in Benue State, Nigeria. Journal of social science, 24(2): 143-148.

Ukwu, I. U., Anyanwu, E. A., Imaga, E.U. L., Akwuba, M., Ofong, I., Nwakobu, F., Omeje, K., Onyeukwu, O. E., Umoh, B. D., \& Uguonah (1998). Enugu State poverty report, 'Institute for Development Studies University of Nigeria Enugu Campus, Enugu.

Umoh, G. S. (2006). Resource-use efficiency in urban farming: An application of stochastic frontier production. International journal of agriculture and biology, 2006; 8(1): 38-44.

USDA (2019). United States Department of Agriculture. Foreign Agricultural Services. Accessed on November 28, 2020, from the website https://apps.fas.usda.gov.

USDA (2018). Grain and Feed Annual: 2018 West African Rice Annual (Grain Report). Global Agriculture Information 

$63-74$

\section{APPENDIX}

Table 1: Distribution of lowland rice farmers in the study area

\begin{tabular}{llll} 
Zone & \multicolumn{2}{l}{ Communities } & No of Rice Farmers Selected \\
Agwu & - & Oduma & 40 \\
& - & Okpanka & 40 \\
Sub-Total & & Nenwe & 20 \\
Nsukka & - & Adani & 80 \\
& - & Asaba & 20 \\
Sub-Total & & & 100 \\
Agbani & - & Ugbawka & 30 \\
& Amagunze & 21 \\
Sub-Total & & & $\mathbf{6 0}$ \\
Enugu East & - & Eha-Amufu & 30 \\
& - & Neke & 10 \\
Sub-Total & & & 40 \\
Grand-Total & & & $\mathbf{3 0 0}$
\end{tabular}

Table 2. Results of maximum probability estimates of stochastic frontier production function of rice farming

\begin{tabular}{|c|c|c|c|}
\hline Variables & Parameters & Coefficients & T.ratio \\
\hline Intercept & $\mathrm{b}_{0}$ & 6.1052 & $18.7543 * * *$ \\
\hline Farm size & $\mathrm{b}_{1}$ & 0.0531 & -1.4331 \\
\hline Labour & $b_{2}$ & 0.0804 & $2.5126^{* *}$ \\
\hline Seed & $b_{3}$ & 0.2319 & $3.8768 * * *$ \\
\hline Fertilizer & $\mathrm{b}_{4}$ & 0.0329 & $5.2735^{* * *}$ \\
\hline Agrochemical & $b_{5}$ & 0.1711 & $2.2043 * *$ \\
\hline \multicolumn{4}{|l|}{ Inefficiency model } \\
\hline Constant & $\mathrm{z}_{0}$ & -4.8490 & -0.9914 \\
\hline Age & $\mathrm{z}_{1}$ & 0.0651 & 1.1458 \\
\hline Farming experience & $\mathrm{z}_{2}$ & -0.0587 & $2.1856^{*}$ \\
\hline Household size & $\mathrm{z}_{3}$ & -0.3768 & -.1788 \\
\hline Educational status & $\mathrm{z}_{4}$ & -0.3524 & $-3.0531 * *$ \\
\hline Extension contact & $\mathrm{Z}_{5}$ & -0.0362 & -.06173 \\
\hline Credit access & $\mathrm{z}_{6}$ & 1.1017 & $2.9587 * *$ \\
\hline Cooperative membership & $\mathrm{z}_{7}$ & -4.3660 & $-4.2564 * *$ \\
\hline \multicolumn{4}{|l|}{ Diagnostic statistics } \\
\hline Sigma squared & $\left(\delta^{2}\right)$ & 0.3209 & 1.2196 \\
\hline Gamma & $(\gamma)$ & 0.9805 & $57.2659 * * *$ \\
\hline Log likelihood function & & -169.5252 & \\
\hline LR of one sided error & & 68.8778 & \\
\hline Number of observation & & 300 & \\
\hline Mean efficiency & & 0.71 & \\
\hline $\begin{array}{l}\text { Source: Computed from fi } \\
* * * \text { Notable at } 1 \%\end{array}$ & $\begin{array}{l}\text { ta computer } \mathrm{fr} \\
\text { Notable at } 5^{\circ}\end{array}$ & $\begin{array}{r}4.1 \mathrm{c} \text { version } \mathrm{p} \\
* \text { Nota }\end{array}$ & \\
\hline
\end{tabular}


Table 3. Summary statistics of technical efficiency of rice farms

\begin{tabular}{lll}
\hline \multicolumn{3}{c}{ Technical efficiency } \\
Efficiency level & Frequency & \% \\
\hline$<0.20$ & 4 & 1.3 \\
$0.2-0.40$ & 28 & 9.3 \\
$0.41-0.60$ & 31 & 10.3 \\
$0.61-0.80$ & 116 & 38.7 \\
$081-1.00$ & 121 & 40.3 \\
Total & $\mathbf{3 0 0}$ & $\mathbf{1 0 0}$ \\
Minimum & & 0.11 \\
Maximum & & 0.94 \\
Mean & & 0.71 \\
Standard deviation & & 0.19 \\
\hline
\end{tabular}

Source: Computed from Field Data Computer 4.1c Version Print-out 